\title{
Job satisfaction over the life course
}

David G. Blanchflower Alex Bryson

Quantitative Social Science

Working Paper No. 20-20

December 2020 


\section{Disclaimer}

Any opinions expressed here are those of the author(s) and not those of the UCL Social Research Institute. Research published in this series may include views on policy, but the institute itself takes no institutional policy positions.

QSS Workings Papers often represent preliminary work and are circulated to encourage discussion. Citation of such a paper should account for its provisional character. A revised version may be available directly from the author.

Quantitative Social Science

UCL Social Research Institute

University College London

\section{5-59 Gordon Square}

London WC1H 0NU 


\title{
Social Research Institute
}

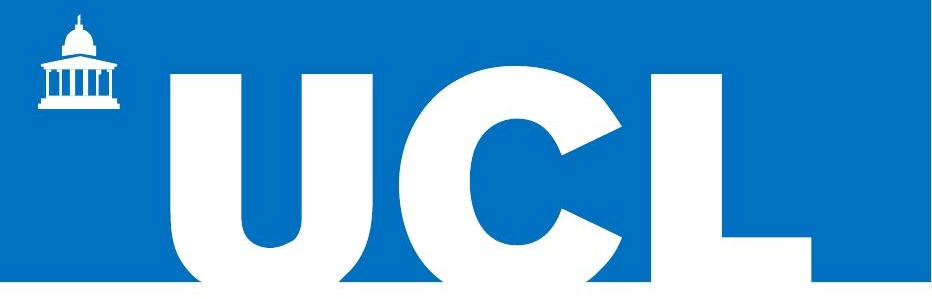

\section{Job satisfaction over the life course}

\author{
David G. Blanchflower ${ }^{1}$ \\ Alex Bryson ${ }^{2}$
}

\begin{abstract}
We examine the relationship between union membership and job satisfaction over the life-course using data from the National Child Development Study (NCDS) tracking all those born in Great Britain in a single week in March in 1958 through to age 55 (2013). Data from immigrants as well as nonrespondents to the original 1958 Perinatal Mortality Study (PMS) are added in later years.

Conditioning on one's social class at birth, together with one's education and employment status, we find there is a significant negative correlation between union membership and job satisfaction that is apparent across the life-course. Lagged union membership status going back many years is negatively correlated with current job satisfaction, though its effects become statistically non-significant when conditioning on current union membership status. These results provide a different perspective to longitudinal studies showing short-term positive responses to switches in membership status. They are consistent with earlier work showing that this cohort of workers, and others before them, have persistently lower job satisfaction as union members compared to their non-union counterparts.
\end{abstract}

Keywords: : union membership; job satisfaction; life-course; birth cohort; National Child Development Survey (NCDS).

JEL Codes: J28; J50; J51

Acknowledgements: Alex Bryson would like to thank the Norwegian Research Council (grant no. 301280/H20) for financial support. We thank Benjamin Artz, Andrew Clark, Carol Graham, Colin Green, Heather Joshi and Bozena Wielgoszewska for useful discussions and comments and Peter Elias for introducing Danny Blanchflower to the NCDS over thirty years ago.

\footnotetext{
${ }^{1}$ Bruce V. Rauner Professor of Economics, Department of Economics, Dartmouth College. Adam Smith Business School, University of Glasgow. GLO, Bloomberg and NBER Blanchflower@dartmouth.edu

2 Professor of Quantitative Social Science, UCL Social Research Institute, University College London. NIESR and IZA, a.bryson@ucl.ac.uk
} 


\section{Introduction}

For many decades the negative partial correlation between union membership and job satisfaction was taken as a given. Together with a positive union wage gap (Lewis, 1963; Freeman and Medoff, $1984-$ F\&M henceforward) and lower quit rates among union members (F\&M, 1984) it was regarded as one of the empirical regularities in labour economics. It attracted much attention subsequently because the finding appeared at odds with the objectives of trade unionism, which are to improve the terms and conditions of their members relative to what they might have been offered in the absence of a trades union.

Some studies indicated the partial correlation was biased by unobserved traits of workers or their jobs that simultaneously affected membership status and job satisfaction. Most notable were the studies indicating workers with a tendency towards job dissatisfaction sorted into union membership, perhaps because they had character traits which meant they were permanently less satisfied than non-members, and those studies suggesting union dissatisfaction arose because the unionized were in poorer jobs, or experienced worse working conditions, than their non-member counterparts, and thus sought union representation to address their problems.

Both arguments garnered support from empirical studies. Some identified poorer working conditions - such as a poor climate of industrial relations (Bender and Sloane, 1998) - as a trigger to membership. Others found the negative partial correlation between membership and job satisfaction became statistically non-significant, or even positive, when using person fixed effects models which focused purely on the within-person variance in job satisfaction associated with switches in union membership status. These studies provided some support for the proposition that the negative partial correlation may have been driven by innate, otherwise unobserved, dissatisfaction of workers who joined unions. However, further investigation using event-study analyses revealed that, whilst those about to enter membership did experience substantial job dissatisfaction, this switched around on joining the union, such that they became more satisfied than they had previously been - albeit for a limited period (Powdthavee, 2011).

This literature turned another corner recently when Blanchflower and Bryson (2020) found the negative partial correlation between union membership and job satisfaction observed in the early studies of F\&M and Borjas was no longer apparent in recent surveys. Indeed, the partial correlation had become positive and statistically significant. The authors speculate about potential reasons for this turnaround but one, which is apparent in the data, is that more recent entrants to union membership felt more positively about their jobs than workers born some years ago who had entered union membership decades before. The authors had no ready explanation for this switch in cohort effects underling the new-found positive correlation between union membership and job satisfaction, but they did speculate that, if the cohort trends were to continue, the correlation between membership and job satisfaction may become more positive over time.

In this paper we revisit this issue by focusing on the relationship between union membership and job satisfaction among a cohort of workers born in Britain in the same 
week in 1958. We track these individuals through to age 55 to examine the association between union membership and job satisfaction over the life-course. In doing so we focus on the birth cohort which would have been entering the labour market around the time F\&M (1984) and Borjas (1979) were conducting their studies. These are workers who, at least in the early years of their lives, we might expect to exhibit a negative correlation between their union membership and job satisfaction. Subsequent analyses by Blanchflower and Bryson (2020) for the United States using cross-sectional data suggest the link between union membership and job satisfaction remained negative for this cohort of workers. Artz et al (2020) explore this issue using panel data for the United States and the UK. We wish to establish whether this is indeed the case for workers from this British birth cohort.

The rationale for our study has a second motivation: whilst others have used longitudinal data on individuals over time to examine links between union membership and job satisfaction, the focus has been either on comparing OLS estimates with worker fixed effects models - to isolate the effects of changes in membership on job satisfaction within individuals over time - or else to undertake event studies which estimate changes in job satisfaction shortly before and shortly after a switch in union membership status. What is lacking from the literature is an appraisal of the links between union membership and job satisfaction over the whole life-course. This is something we offer for the first time in this paper.

The rest of the paper proceeds as follows. Section Two discusses the previous literature using panel data to investigate the links between unionization and job satisfaction, and comments on the value of a life-course investigation of the issue. Section Three presents the National Child Development Study (NCDS) data and the methodology used to capture union effects on job satisfaction. Section Four presents results before we conclude and comment on implications in Section Five.

\section{Literature}

The earliest studies on the relationship between unionization and job satisfaction used annual panel data on individuals from household surveys to unpick the relationship between changes in union status and changes in job satisfaction. There are a couple of strands to this research. One strand considered the potential for omitted work-related variables to explain the job dissatisfaction of unionized workers. A second considers the types of individuals who become unionized and whether they differ in unobserved ways from those who are not unionized. We take each strand in turn.

Recognizing that unions are more likely to be able to organize poorer jobs in poorer working environments, and that unions seek to improve the wages and working conditions of unionized workers, analysts have investigated whether unions do indeed organize workers in poorer jobs and, having done so, whether they improve their working conditions. The first to do this were Duncan and Stafford (1980). Using the Panel Study of Income Dynamics (PSID) they examined changes in wages and working conditions for those joining unions, those leaving unions, those remaining unionized and those who remained non-unionized. They found those joining a union experienced a substantial wage 
hike compared to other workers, but a deterioration in their working conditions, results which they thought were consistent with unions procuring a compensating wage differential for union workers' exposure to poorer conditions. Although they don't consider employee perceptions of their jobs, the implication is that, if unionized workers are fully compensated for their poorer jobs through higher wages, their utility from the job will be similar to that obtained from a 'better' but less well-paid job. Consequently, their job satisfaction - if treated as an indicator of the utility workers derive from their jobs would be unlikely to differ from those of similar non-unionized workers.

Their findings were immediately challenged by Leigh (1981). Using panel data from the National Longitudinal Study (NLS) he investigated changes in employee perceptions of their jobs, including "progress at work" which, he argued (p. 1051), was akin to a job satisfaction metric, as well as pace of work, fatigue and job pressures. In contrast to Duncan and Stafford (1980) he found little evidence that these changed with union status, concluding that Duncan and Stafford's findings regarding unions procuring compensating wage differentials did not generalize to the young men in the NLS. Leigh went further, suggesting that perceived working conditions in the union sector were "at least equal to" (p. 1054) those in the non-union sector "as would be expected if, despite their higher wages, organized workers have a direct impact through their unions in altering disagreeable working conditions".

Leigh underscores this point by noting a reduction in perceived job pressures among union stayers, compared to non-union stayers, while holding wages constant, consistent with union workers "[making] progress in their work" (p. 1054). His conclusion is that "channels of collective voice encourage the expression of dissatisfaction while simultaneously restraining dissatisfied workers from leaving their employers", giving credence to the causal impact of unions in being able to extend worker tenure through the expression of, and actions to address, worker dissatisfaction.

A slightly earlier paper by Borjas (1979) is also directly pertinent to this debate. It is largely based on cross-sectional data from the National Longitudinal Survey of Mature Men aged between 50 and 64 years of age when the survey was conducted in 1971. It considered union effects on job satisfaction directly, recognizing the possibility that the dissatisfaction among union members could conceivably arise due to their organizing of poorer jobs. Borjas addresses this reverse causality issue in two ways.

First, Borjas runs a simultaneous equation in which union membership and job satisfaction are jointly determined, instrumenting for union membership with industry dummies. Union membership is found to be associated with higher job dissatisfaction, even when instrumented, a finding that is consistent with the proposition that unions do raise job dissatisfaction and that they do so through a voice mechanism which politicizes workers as they seek better terms and conditions. Exploring this further Borjas considers union effects on job satisfaction for long- and short-tenure workers, arguing that voice effects imply greater job dissatisfaction among longer-tenure workers. This is precisely what he finds. He goes on to find that this effect is not compensated for by seniority pay. On the contrary, it appears the union wage effect diminishes with tenure. In the one panel element 
in Borjas' study, he examines quit rates as a function of unionization over the period 19691971. He confirms the negative effect of unionization on quits but notes that it is much stronger at lower tenure levels, becoming weaker with seniority and even positive after 25 years of tenure (p. 35), consistent with unions flattening earnings profiles as workers remain in the same job. Taken together Borjas's (1979) analyses are in line with those of Leigh (1981) in supporting the exit-voice hypothesis and run counter to Duncan and Stafford's (1980) finding that unions procure compensating wage differentials.

In his analyses for the United States using the National Longitudinal Survey of Youth (NLSY) 1979-2004, Artz (2010) emphasizes the importance of past union experience for current job satisfaction, in addition to current membership status. Failure to account for past union experience effectively means that all current non-members are treated the same - as if they had never experienced unionization. Accounting for past union experience proves important empirically since the negative association between unionization and job satisfaction increases with union experience. Conversely, as time since last unionization grows, so job satisfaction rebounds, becoming more positive. Artz interprets the latter as a fading of the politicization which, as Borjas (1979) notes, comes with union voice and bargaining. In the analyses we present later we therefore incorporate lagged union status to see what effect, if any, it has on job satisfaction.

There is a long-standing parallel literature for Britain using panel data. ${ }^{3}$ Some of this has focused on union coverage - that is, whether an individual is in a job whose terms and conditions are set via union bargaining - whilst other papers focus on union membership. The distinction is a potentially meaningful one for Britain because, unlike the United States where there is a strong positive correlation between membership and coverage, the British industrial relations system means many of those whose pay is set via union bargaining (covered workers) may not be union members - that is, they 'free-ride' on union bargaining. Conversely, there are some members whose terms and conditions are not subject to collective bargaining. ${ }^{4}$

\footnotetext{
${ }^{3}$ There is also a literature for Britain which relies on cross-sectional data to investigate whether union effects on job satisfaction persist when one accounts for unobserved worker or workplace effects. Bender and Sloane (1998) find the association between unionization and job satisfaction becomes statistically nonsignificant when they instrument for union status with perceptions of the climate of industrial relations at the workplace. Bryson et al. (2004) obtain similar results using linked employer-employee data instrumenting for union membership using employer perceptions of the climate of industrial relations. The distinction between union coverage and union membership is found to be important in Bryson et al. (2010) who find that, having instrumented for coverage using workplace age and the workplace belonging to a multi-site firm, the link between membership and job dissatisfaction is confined to uncovered union members.

${ }^{4}$ In both countries, workers are protected from penalties associated with being, or not being, a union member. However, in the United States, in all but the "right-to-work states", employees can be required to pay the equivalent of union dues if they are employed in a workplace where a union is recognized for bargaining purposes. In the United Kingdom, the closed shop (requiring an individual to be a union member in order to perform a particular job) was only outlawed in the late 1980s (whereas it had been illegal in the United States since 1947), such that union membership has only been an unfettered choice for all workers since the 1990s. This is worth recalling when we come on to the empirical analysis presented later because employees in NCDS may have been subject to the closed shop (depending on the industry and occupation they worked in) up until the time shortly before the NCDS fourth survey sweep in 1991.
} 
Bryson and White (2016a) examine associations between changes in employees' satisfaction with various aspects of their job and changes in union coverage. Using panel data from the British Household Panel Survey (BHPS) (1991-2007) which follows up on individuals annually they show that when employees move into a union covered job they receive a wage mark-up and, perhaps unsurprisingly, report higher pay satisfaction. Conversely, those moving from a union covered job on average lose any mark-up and have significantly reduced pay satisfaction. Similar findings emerge for working hours which, they show, are also often the object of union bargaining: workers prefer shorter hours and achieve them with a switch into union coverage, resulting in higher satisfaction with working hours. However, switching into union coverage lowers satisfaction with job security, even though coverage has no effect on the perceived risk of unemployment. This is because covered employees suffer greater costs of re-employment at any given level of employment risk, partly due to the loss of the union wage mark-up. These findings are consistent with unions' ability to improve employees' working conditions and wages, resulting in improvements in those facets of the job where unions bargain successfully.

A second strand of the literature has examined the possibility that those workers who unionize are different from those who do not in ways that affect their propensity to report job dissatisfaction. If the difference is unobserved but fixed over time, then this differential propensity for dissatisfaction among unionized workers will disappear with the introduction of person fixed effects into the job satisfaction equation. Of course, as in the case of the panel analyses seeking to account for differences in working conditions, the identification of union effects is reliant on those switching union status. A series of panel studies have regressed union status on job satisfaction, treating it as exogenous. They tend to find a negative association between job satisfaction and unionization which falls and becomes statistically non-significant, or even turns positive, when incorporating person fixed effects which account for otherwise fixed unobserved differences across individuals. ${ }^{5}$

This is the case, for example, in the study by Bryson and White (2016b) using 17 sweeps of BHPS data for the period through to 2008: negative associations between union coverage and satisfaction with pay and hours become positive and statistically significant with the incorporation of person fixed effects. ${ }^{6}$ Blanchflower and Bryson (2020) find similar effects when comparing OLS and person fixed effects models for unionization effects on overall job satisfaction over the period 1996-2014 using panel data combining BHPS with its successor Understanding Society (USoc). ${ }^{7}$ The implication is that, at least among

\footnotetext{
${ }^{5}$ Not all effects move in the same direction. For example, in Heywood et al.'s (2002) study of the BHPS for the period 1991-1994 a negative union membership coefficient in a pay satisfaction regression becomes statistically non-significant with the incorporation of person fixed effects. However, negative associations between membership and satisfaction with "relations with the boss" and "work itself" persist with the incorporation of person fixed effects.

${ }^{6}$ In their study of BHPS data for 1995-2008 Green and Heywood (2014) find the introduction of worker fixed effects systematically reduces the size of the negative regression coefficients for unionization with respect to satisfaction with all aspects of the job.

${ }^{7}$ The results are robust to the use of union membership or a dummy variable where unionization is either membership or union coverage.
} 
employees in the 1990s and 2000s in Britain, unionized workers had a higher propensity for dissatisfaction than their non-union counterparts, a propensity which may have influenced their union status in the first place.

Conscious of the potential endogeneity of switches in union coverage status, Bryson and White (2016b) distinguish between different paths into coverage. They find union coverage effects on pay satisfaction are strongest where coverage is extended to an employee who remains in the same job, with the same employer. This, they argue, is likely a more exogenous switch than those accompanying a job switch, thus providing further weight to the proposition that unions may have a causal impact in raising employee job satisfaction through pay bargaining.

Another important finding in the literature is that union-induced changes in job satisfaction vary over time. This is what Artz (2010) found for the United States. It is perhaps best illustrated for Britain in the paper by Powdthavee (2011) for private sector employees in waves 5-15 of the BHPS. Using panel fixed effects estimates he shows job satisfaction declines in the year prior to becoming unionized, relative to those who remain non-union - as one might expect if dissatisfaction with one's job triggered the desire to become a union member. This is followed by an initial positive impact of being newly unionized on several aspects of job satisfaction. However, this positive effect only persists in the case of pay satisfaction, which is perhaps the issue which unions devote most time and effort to in bargaining with employers. ${ }^{8}$

This review suggests that unionization tends to be negatively correlated with job satisfaction when treated as exogenous; the effects become non-significant and, in some cases positive when instrumenting for unionization and when fixed unobserved differences across workers are accounted for; and that unionization effects are most likely positive in the case of pay satisfaction, reflecting the wage bargaining efforts of trade unions which raise union workers' wages above those set in the market. However, there is some uncertainty as to how long these union effects persist, and there may also be a causal impact of unionization inducing job dissatisfaction through the politicizing effects of union voice and bargaining.

The bulk of this literature focuses on short-run effects of unionization - usually change over one year or, in some cases, a few years in succession. There is no literature investigating union effects over the life-course, though there are suggestions in the work by Borjas (1979) that union wage effects diminish with tenure, leading to greater job dissatisfaction among older unionized workers. Furthermore, only recently in the work of Blanchflower and Bryson (2020) has it become apparent that union associations with job satisfaction differ markedly by birth cohort, as well as age. Among those cohorts born more recently unionization is more positively associated with job satisfaction: unionized employees born in the 1950s and 1960s have lower job satisfaction than their non-union counterparts, a difference that persists over time.

\footnotetext{
${ }^{8}$ Bryson and White (2016b) also test for the persistence of union positive effects on job satisfaction and find that the effects of union coverage on pay satisfaction do not persist over time.
} 
In the remainder of this paper we turn to union effects on job satisfaction across the lifecourse for a British birth cohort born in 1958 who were entering the labour market in the late 1970s and who we track through to age 55 in 2013.

\section{Data and Estimation}

Our data are the British National Child Development Study (NCDS), a nationally representative cohort study of all the people born in England, Scotland and Wales in a single week in March, in 1958 (Pearson, 2016). In addition, 798 immigrants born in that week but outside Great Britain and 345 who were born in Great Britain, but who were not in the initial Perinatal Mortality Study (PMS) were later added. In total there are 18,558 study participants of whom 18,059 are white. There were 395 stillbirths and 278 neonatal deaths in the first 28 days of life and by age 55, in NCDS9, there had been an additional 987 deaths. In addition, there was an attempt made in 2013 to contact those once in Britain but now living abroad, to invite participation in a web-based follow-up at age 55 (Dodgeon et al, 2014). At NCDS9 1,286 study participants had emigrated.

We track the job satisfaction and union status of those in employment at ages $23,33,42$, 46, 50 and 55 - respectively sweeps 4 through 9 of the data. All but the telephone survey at age 46 involved a home interview. The cohort started as the Perinatal Mortality Study (PMS) with 17,415 births covering $98 \%$ of births in that week. Individuals frequently disappear in one sweep and reappear in a subsequent one. In NCDS4 at age 23 there were 12,537 observations; 11,469 in NCDS5 at age 33, 11,419 in NCDS6 at age 42; 9534 in NCDS7 at age 46; 9,790 in NCDS8 at age 50 and 9,137 in NCDS9 at age 55. At age 55 approximately $86 \%$ of the sample had responded to NCDS4.

Response rates to these surveys have been high. Below we tabulate percentage distributions for all cohort members in 2013 based on the social class of the cohort member's mother's husband in 1958 at the time of the respondent's birth (variable n492). By 2013 there were 1,659 respondents who had died: they were disproportionately from Social Class 5. Overall 1,286 had emigrated, disproportionately from Social Classes 1 and 2 and those who had not been in the original PMS file, presumably returning to their country of origin outside the British Isles. Excluding those who had died and those who had emigrated, the response rate at NCDS9 was 58.5\%. The distribution of nonrespondents in column 5 is slightly more weighted to the lowest two social classes than those who are present in NCDS9 (22.6\% versus $17.6 \%)$, suggesting sample selection by social class was not a major problem.

$\begin{array}{lrrrrr} & \text { All } & \text { In NCDS9 } & \text { Emigrated } & \text { Dead } & \text { Not in NCDS9 } \\ \text { Other } & 2.3 & 2.1 & 2.8 & 2.8 & 2.5 \\ 1 & 4.0 & 4.9 & 5.8 & 2.3 & 2.8 \\ 2 & 11.4 & 13.6 & 12.1 & 9.3 & 9.0 \\ 3 & 53.8 & 54.6 & 52.3 & 56.5 & 52.2 \\ 4 & 10.8 & 10.6 & 8.2 & 10.6 & 11.6 \\ 5 & 8.7 & 7.0 & 5.1 & 12.0 & 11.0 \\ \text { No husband } & 2.8 & 2.1 & 3.0 & 3.6 & 3.4 \\ \text { Not in PMS } & 6.2 & 5.1 & 10.7 & 2.7 & 7.6 \\ \text { N } & 18558 & 9137 & 1286 & 1659 & 6476\end{array}$


We present models estimating three sets of dependent variables. First, we estimate job satisfaction equations at sweeps 4 (age 23), 7 (age 46), 8 (age 50) and 9 (age 55). In most of the analyses the dependent variable is overall job satisfaction, but we also present satisfaction with facets of the job at sweep 4 (age 23) which is the only age at which this richer set of job satisfaction variables is available. We everywhere restrict the sample in each sweep, including lagged values, to workers only. Although the satisfaction variables are ordinal, running from very dissatisfied to very satisfied, we run OLS estimates. ${ }^{9}$ The models are run for single sweeps of data and incorporate the same set of controls throughout, namely gender, region and education, together with employment status (parttime employee, self-employed). We also present extended models which incorporate the cohort member's social class, as indicated by the occupation of his or her father at birth.

Union status is captured by the cohort respondent's union membership status. We experiment with contemporaneous union membership, together with lagged union membership in previous waves to assess the persistence of union membership effects. Throughout estimates are unweighted.

Second, we run log hourly wage equations for employees at sweep 4 (age 23) and sweep 8 (age 50) to establish the size of the wage gap between union members and non-members.

Third, when employees are aged 50 in sweep 8 they are asked a broader range of subjective wellbeing questions, such as how much pain they feel at work, and whether they would pack in their job if they disliked it. These models control for social class, region and education, as well as the cohort member's gender and current employment status (parttime, self-employed). These models capture the partial correlation between five wellbeing metrics and contemporaneous union membership status.

\section{Results}

By age 23, of the 12,536 individuals who responded to the NCDS4 survey $73.6 \%$ were in employment. Of these $44.3 \%$ were union members. Recall, this was 1981 when union membership in Britain was close to its peak (Chart 1). Union membership was 13.2 million in 1979; 12.6 million in 1980 and 12.3 million in 1981. It fell dramatically afterwards as examined by Disney (1990) and Disney, Gosling and Machin (1995) such that, by 2013 when we last see our birth cohort at age 55 - membership had dropped to 7.0 million. ${ }^{10}$ This is reflected in the NCDS birth cohort: union membership had halved to $21.3 \%$ by 2008 when they were aged 50 (Appendix Table A1).

\footnotetext{
${ }^{9}$ Throughout results are robust to the use of an ordered probit estimator.

${ }^{10}$ It continued to fall until 2016 when it stood at 6.23 million, rising to 6.4 million in 2019 ('Trade Union Membership, UK, 1995-2019: Statistical Bulletin', 27 May 2020, Department for Business, Energy and industrial Strategy).
} 
In addition, unemployment was rising quickly under Margaret Thatcher's premiership. The UK monthly unemployment rate rose steadily during 1981 from $8.6 \%$ in January through to $10.3 \%$ in December, a rate it has never reached since. ${ }^{11}$

Table 1 recovers the partial correlation between union membership at age 23 and five measures of job satisfaction using OLS estimates. The first is an overall measure of job satisfaction (n4320). The four others relate to pay (n4313); physical conditions (n4316), job organization (n4317), and interest in their job (n4319). They are taken from the following question:

"I am going to read out some things which affect how people feel about their job. Can you tell me how satisfied or dissatisfied you feel with each one in your present job - very satisfied (=5); satisfied (=4); neither (=3); dissatisfied $(=2)$ very dissatisfied $(=1)$ - with our codes in parentheses -

Q1. Your usual take home pay?

Q2. Your physical working conditions?

Q3. The interest and skill involved in your job?

Q4. The way your firm is run?

Q5. Taking everything into consideration how satisfied or dissatisfied are you with your job as a whole?"

Each equation includes controls for gender, part-time and self-employed status, region and education levels. (There is no age control since all are aged 23).

At age 23,30\% of employees reported being 'very satisfied' with their current job, and another half $(49.8 \%)$ reported being 'satisfied'. Only 3\% were 'very dissatisfied' Nearly four-fifths of employees continued to report being either "satisfied" or "very dissatisfied" with their jobs in the other three sweeps when job satisfaction is asked, namely at ages 46, 50 and 55 (Appendix Table A1).

We had anticipated that the partial correlation between union membership and overall job satisfaction would have been negative and statistically significant given the earlier literature identifying such a relationship for this birth cohort, albeit in the United States. In fact, although the coefficient in column 1 of Table 1 is negative it is far from statistically significant (with a t-statistic of 0.27). However, a clear pattern emerges in columns 2-5

\footnotetext{
${ }^{11}$ Being part of a large cohort entering the world of work can reduce future prospects (Korenman and Newmark, 2000). We looked at the UK mid-year population estimates and found that the number age 23 in 1981 was $1.48 \%$ of the population, which compares with an average from 1971-2014 of $1.42 \%$. The size of the age 23 cohort was on a rising trend from $1.36 \%$ in 1978 to a peak of $1.88 \%$ in 1988 before falling back to $1.15 \%$ in 2000 . This compares with $1.2 \%$ in 2020 . The number age 23 in 1981 was greater than the number in $2020(833,717$ versus 815,851$)$ despite a rise in the population of by nearly 11 million from 56.3 million to 67.2 million. Source: UK Population Estimates, 1851-2015, ONS July 2015 and Census Bureau International Database.
} 
when we consider the association between union membership and satisfaction with various facets of one's job. Union members rate their jobs more poorly than their non-union counterparts on all non-pecuniary components (physical conditions, job organization, job interest) but express greater satisfaction with their pay. These results are very much in keeping with the compensating wage differentials idea initially discussed by Duncan and Stafford (1980). The final column lends further support to this proposition: the union coefficient in the overall job satisfaction equation increases ten-fold relative to column 1 and becomes statistically significant (with a t-statistic of 2.37) when conditioning on log hourly pay. This is reminiscent of Borjas' (1979: 31) analyses for the United States in the early 1970s when he compared union effects on job satisfaction with and without a wage control.

To establish the precise size of this union wage premium we ran some estimates of log hourly wages in NCDS4 for workers aged 23 (Appendix Table A2). We find a union wage premium of around $20 \%$ which hardly changes with the introduction of controls for education, part-time status and region dummies (column 2 compared to column 1). ${ }^{12}$ This estimate is somewhat larger than found in 1980 in Blanchflower (1984) for all workers.

$\begin{array}{lccccc} & \text { All } & <25 & 25-34 & 35-49 & 50+ \\ 1990 \mathrm{~s} & 20.7 \% & 26.4 \% & 18.1 \% & 20.0 \% & 20.1 \% \\ 2000 \mathrm{~s} & 14.5 \% & 19.8 \% & 13.5 \% & 14.5 \% & 16.3 \% \\ 2010 \mathrm{~s} & 13.4 \% & 23.1 \% & 15.2 \% & 11.3 \% & 14.7 \% \\ \text { All } & 16.3 \% & 22.2 \% & 15.0 \% & 15.4 \% & 17.3 \%\end{array}$

We examined the UK Labour Force survey which contains data on earnings and union status from 1993-2019 which is the same survey (1993-2006) used in Blanchflower and Bryson (2010). We estimated a series of log hourly earnings equations by four age groups and three time periods controlling for year, region, age and its square, gender and age left school $(n=331,250)$. It is clear that union wage differentials were highest in the 1990s for all age groups. In each time period, though, wage differentials were highest for the young.

As we see in columns 3 and 4 of Appendix Table A2 at age 50 the raw union wage premium is $9 \%$ but it falls to zero with controls. Again, this is reminiscent of Borjas' (1979) analysis for the United States which showed union effects on wages turned negative among men in their 50 s who had been in their jobs for some time. ${ }^{13}$

Ideally, we would have assessed the partial correlation between union membership and job satisfaction in all NCDS sweeps but, as we see in Appendix Table A1, job satisfaction is not available in NCDS5 (age 33) and NCDS6 (age 42). It is available in NCDS7 when cohort members were aged 46. It is notable that their job satisfaction in general rises relative to the job satisfaction of those in employment at age 23: almost half (46\%) report that they are 'very satisfied' with their job. Unfortunately, union membership is not

\footnotetext{
${ }^{12}$ The union wage differential in percentage terms is obtained by taking anti-logs and deducting 1.

${ }^{13}$ Although among Borjas' survey of men in their 50s and 60s back in 1971 the average union effect on wages having conditioning on tenure and other controls was nevertheless positive and statistically significant (.0485, t-stat $=2.02$ from Table 5$)$.
} 
recorded in NCDS7. Instead, in Table 2 we consider the partial correlation between job satisfaction and past union membership status among those at age 46, in 2004, in NCDS7. The motivation for doing so is to assess the persistence of union effects, as explored by Artz (2010) for the United States.

The exact question (n7jbsatis) asked was very similar to Q5 above.

Q6. All things considered, are you satisfied or dissatisfied with your present job-very satisfied (=5); satisfied (=4); neither (=3); dissatisfied (=2) very dissatisfied (=1) once again with our codes in parentheses.

As in the case of 23 year olds, we find 46 year olds in this cohort were more satisfied with their jobs overall working as self-employed or part-time, when compared to working as full-time employees, whilst men were less satisfied with their jobs than women (Table 2, column 1).

If unionized in NCDS6, when aged 42, workers were likely to be less satisfied with their jobs at age 46 than those who had been working but were not unionized at age 42 (column 2). Being unionized at NCDS5 when aged 33 was also negatively and significantly correlated with job satisfaction at age 46 (column 3). Effects of union membership at age 23 were negative but non-significant (column 4). The implication is that duration of union experience is strongly associated with lower job satisfaction, as Artz (2010) found for the United States. That said, current membership is salient, as indicated when we condition on both current membership status at age 46 and lagged membership when aged 42 (column 5) and when we include lagged union status at ages 42 and 33 (column 6).

We conduct a similar exercise in Table 3, but this time for job satisfaction at NCDS8 when workers were aged 50. The exact question (n8jbatis) used was Q6 above. In this case, we have contemporaneous union membership: this is strongly and negatively associated with job satisfaction at age 50 (column 1). When entered alone, lagged union membership is also partially correlated with job satisfaction at age 50, whether measured at age 42 (column 2), 33 (column 3) or 24 (column 4). Again, when entered together, it is contemporaneous union membership status that remains negative and statistically significant (columns 5 and 6).

A similar pattern of results emerges in Table 4 when we focus on job satisfaction in NCDS9 when workers are aged 55. The question used (jobsatis9) was Q6 above. When entered separately lagged union membership is negatively and significantly associated with job satisfaction at age 55 - even union membership some 22 years earlier when aged 33. (Union membership at NCDS4 was excluded as it was always insignificant). However, once again, contemporaneous union membership is negative and significant and substantially reduces the coefficient on lagged membership such that membership at age 42 (NCDS6) becomes non-significant when it is included in column 5. Finally, in column 6 we included lagged job satisfaction at age 50: unsurprisingly it is very strongly correlated with job satisfaction at age 55 but, even here, the partial correlation between membership and job satisfaction at age 55 remains negative and statistically significant. The implication is that, even if one 
partials out dissatisfaction with a job 5 years previously, union membership continues to generate dissatisfaction with the job now.

One possible hypothesis that can be tested in NCDS is that the association between union membership and job dissatisfaction is actually driven by a third, usually unobserved, factor namely one's family origins which potentially generate both a greater propensity for union membership and job dissatisfaction. We know from other research that union membership is passed inter-generationally (Bryson and Davies, 2019) but little is known about one's social origins at birth and the propensity for job satisfaction. We can test for this in NCDS because it contains data on the occupation of the respondent's father when they were born. ${ }^{14}$ We plug this variable into estimates of job satisfaction at ages 23, 55, 50 and 46 in Table 5. We also include an (insignificant) control for whether the respondent was not in the PMS which means no father's occupation was not reported, to maintain sample sizes. We find that one's social class at birth, as indicated by one's father's occupation, does indeed significantly impact one's own job satisfaction up to 55 years later. However, the negative partial correlation with union membership remains negative and statistically significant in all but NCDS4.

Blanchflower and Bryson (2020) reported that the partial correlation between unionization and job satisfaction was positive in post Great Recession data, but so too was its partial correlation with other well-being measures including life satisfaction, happiness and lowered stress and worry. But they also found that unions entered positively in pain and anger equations in the Gallup US Daily Tracker from 2008-2017.

With these findings in mind we repeated this exercise for a range of wellbeing metrics (Q6Q10) in NCDS which were collected in 2008 when cohort members were aged 50. Results are reported in Table 6 . We find union members at age 50 are likely to report more pain (column 1) and more pain at work (column 2) than their non-union counterparts, reminiscent of the Gallup Daily Tracker results mentioned above. In addition, union members were more critical of management than non-members: they were more likely to agree with the statement that managers always try and get the best of workers (column 3).

Of note is that in all three equations the occupation of the respondent's father when they were born, as recorded in the 1958 PMS, has an impact on well-being fifty years later. The final column indicates that, despite expressing greater dissatisfaction with their jobs and management at age 50 compared to their non-member counterparts, they were nevertheless more attached to paid work than non-members: they were less likely to agree that they would pack up a job they disliked, even if they had no other to go to. Father's occupation was not a significant influence in the final column so was omitted. These responses provide some insights into why union members invest in unionization in the first place: they prefer to voice to improve their job as opposed to simply putting up with a bad situation.

\section{Conclusions}

Using data from a cohort of 18,558 individuals born in a single week in March 1958, in Great Britain or who were immigrants born in that week in another country, we examine

\footnotetext{
${ }^{14}$ The data actually refers to the occupation of the respondent's mother's husband.
} 
the relationship between union membership and job satisfaction over the life-course through to age 55 (2013). We find a significant negative partial correlation between union membership and job satisfaction that is apparent at various points across the life-course. Among those in their early 20s satisfaction with the union wage premium off-sets dissatisfaction with non-pecuniary aspects of the job, acting as a compensating wage differential. Furthermore, lagged union membership status going back many years is negatively correlated with current job satisfaction, though its effects become statistically non-significant when conditioning on current union membership status.

These results provide a different perspective to longitudinal studies showing short-term positive responses to switches in membership status. They are consistent with Blanchflower and Bryson's (2020) earlier cross-sectional analyses for the United States showing that this cohort of workers, and others before them, have persistently lower job satisfaction as union members compared to their non-union counterparts. This contrasts with later cohorts where unionized workers actually have higher job satisfaction than their non-unionized counterparts.

Why is it that, among this cohort, union membership is associated with lower overall job satisfaction across the life-course? There are (at least) two possibilities. The first is that the sorts of jobs organized by trades unions at that time were drawn from the lower end of the job quality distribution, either because they were concentrated in heavy industry and manufacturing, or in 'dirty' or 'dangerous' occupations. We get a hint of that from our analyses of satisfaction with different facets of the job among those aged 23: union members express greater dissatisfaction than non-members about all non-pecuniary aspects of the job but are more satisfied about their pay than non-members. This is because, as we show, unions are successful in procuring a compensating wage differential for the poor job quality their workers face. Duncan and Stafford (1980) argued the situation was similar among workers in the United States in the 1970s. That differential appears to have fully compensated union members for their poor-quality jobs at age 23 , but not subsequently.

But why has this association persisted, when later cohorts of union members express greater satisfaction with their work than non-members? It may be that, despite the changing composition of the unionised workforce associated with the decline in heavy industry and its replacement by services and public sector work, this early cohort may have become 'stuck' in poor quality jobs, incapable of moving onwards and upwards to better parts of the labour market? This is a distinct possibility, particularly in Britain because, as we noted earlier, this cohort were facing a huge economic recession in their early careers. We know that entering the world of work in a recession is particularly hard, potentially limiting future career progression (Kahn, 2010).

A second possibility is that this cohort's experience of unionization is fundamentally different from later cohorts, and that this experience was fashioned early on in their careers. Recall, union density was at its peak in Britain when these workers entered the labour market. And unions were militant. Union recourse to strike action was common and, often, painful for union workers. The working days lost due to industrial action in the 12 months to April 1980 was 32.15 million - the highest for any 12-month period since records began 
in 1931 (Chart 2). It peaked again shortly afterwards, in 1984/85 with the Miners' Strike, as Chart 2 shows. It is conceivable that these experiences accentuated the politicization effect of unionization, something which Borjas (1979) and Artz (2010) identified as important in contributing to a union job dissatisfaction differential, which remained with this cohort of workers through the remainder of their working lives. This might also explain why it is that these workers continue to express dissatisfaction with their jobs, even years later, after their union membership, as indicated by the significance of lagged unionization in our estimates.

One final point is worthy of note. In the 1980s the closed shop was still legally enforceable in Britain. ${ }^{15}$ It meant that some workers were required to be union members prior the entering specific occupations or work settings (a pre-entry closed shop) or on beginning work in that setting (a post-entry closed shop). Twenty-three per cent of workplaces with 25 or more employees had a closed shop for at least some employees in 1980 (Millward et al., 2000: 89). Thus, there were many circumstances in which workers wishing to undertake certain jobs could not do so unless they were union members. This brought many advantages to trade unions and their members, raising union density and thus union bargaining power vis-à-vis employers, leading to a larger union wage premium than in other settings (Stewart, 1987). But it also meant workers had no choice but to be union members and pay union membership fees in many workplaces in Britain at the time. It is possible that many would have chosen not to become unionized at the time if they had had the choice, and that this may have contributed to their dissatisfaction with their working environment.

The world of work had changed in many ways by the time our cohort had reached age 55 in 2013. As we have shown, union membership had fallen dramatically and, as others have shown, those in the union sector had changed quite considerably both in terms of their demographics (most are now women, for example) and in the jobs they undertake (with the majority working in the public sector). Huge structural changes have swept through the economy with the rise of services in place of manufacturing, and the globalization of trade, with attendant implications for workers and their jobs. But this paper suggests that there is some stability in the way in which cohorts of workers feel about their jobs, and the factors influencing those feelings. It seems that these influences affect perceptions and attitudes early in one's working life, and that these persist in the future. We only know this because with birth cohort data we are able to track individuals across their life-course.

There may be lessons for the new generation entering the labour market today. Like their counterparts in the early 1980s, they will be facing huge uncertainty and growing unemployment - albeit for quite different reasons. Whether unions are part of the solution as workers seek improvements in their pay and job quality remains to be seen, but it is notable that in the past three years union membership and union density have been on the rise in Britain, albeit from a low base - the first period of sustained growth since the late 1970s (Bishop, 2020). For this cohort born in a single week in 1958 unionization is negatively correlated with job satisfaction across their lifespan.

\footnotetext{
${ }^{15}$ The 1990 Employment Act made the closed shop unlawful in 1991.
} 


\section{References}

Artz, B. (2010), 'The impact of union experience on job satisfaction,' Industrial Relations, 49(3), pp. 387-405.

Artz, B., D.G. Blanchflower, A. Bryson, A. Clark and C. Green (2020), 'Does unionization raise job satisfaction? Evidence from panel data for the United States and the UK,' working paper.

Bell, D.N.F and Blanchflower, D. G. (2011), 'Youth unemployment in Europe and the United States,' Nordic Economic Policy Review, 1, pp. 11-38.

Bender, K.A. and Sloane, P.J. (1998), 'Job satisfaction, trade unions, and exit-voice revisited,' Industrial and Labor Relations Review, 51(2), pp. 222-240. https://doi.org/10.1177/001979399805100204

Bessa, I., Charlwood, A. and Valizade, D. (2020), 'Do unions cause job dissatisfaction? Evidence from a quasi-experiment in the United Kingdom?,' British Journal of Industrial Relations, 1-29, first online May $18^{\text {th }} 2020$. https://doi.org/10.1111/bjir.12543

Bishop, I. (2020) Trade Union Membership, UK 1995-2019: Statistical Bulletin, Department for Business, Energy and Industrial Strategy. https://www.gov.uk/government/statistics/trade-union-statistics-2019

Blanchflower, D.G. (1984), 'Union relative wage effects; a cross-section analysis using establishment data,' British Journal of Industrial Relations, 22(3), pp. 311-332.

Blanchflower, D. G. and Bryson, A. (2020), 'Now unions increase job satisfaction and wellbeing,' NBER Working Paper \#27720.

Blanchflower, D. G. and Bryson, A. (2010), 'The wage impact of trade unions in the UK public and private sectors,' Economica, 77(305), pp. 92-109.

Blanchflower, D. G. and Bryson, A. (2004), 'What effects do unions have on wages now and would Freeman and Medoff be surprised?,' Journal of Labor Research, 25(3), pp. 383414 and in What Do Unions Do? The Evidence Twenty Years Later (2006) edited by J.T. Bennett and BE. Kaufman.

Blanchflower, D.G. and P. Elias (1999), 'Ability, schooling and earnings; are twins different?,' working paper November.

Blanchflower, D.G. and A.J. Oswald, (1998), 'What makes an entrepreneur?', Journal of Labor Economics, 16(1) pp. 26-60.

Borjas, G. (1979), 'Job satisfaction, wages, and unions,' Journal of Human Resources, 14(1), pp. 21-40. 
Bryson, A. Cappellari, L. and Lucifora, C. (2004), 'Does union membership really reduce job satisfaction?', British Journal of Industrial Relations, 42(3): pp. 439-459.

Bryson, A., Cappellari, L. and Lucifora, C. (2010), 'Why so unhappy? The effects of unionization on job satisfaction', Oxford Bulletin of Economics and Statistics, 72(3), pp. 357-380.

Bryson, A. and Davies, R. (2019), 'Family, place and the intergenerational transmission of union membership,' British Journal of Industrial Relations, 57(3), pp. 624-650

Bryson, A., Joshi, H., Wielgoszewska, B. and Wilkinson, D. (2020), 'A short history of the gender wage gap in Britain,' Oxford Review of Economic Policy, forthcoming.

Bryson, A. and White, M. (2016a), 'Unions and the economic basis of attitudes,' Industrial Relations Journal, 47, 4 pp. 360-378.

Bryson, A. and White, M. (2016b), 'Not so dissatisfied after all? The impact of union coverage on job satisfaction,' Oxford Economic Papers, 68(4), pp.898-919.

Disney, R. (1990), 'Explanations of the decline in trade union density in Britain: an appraisal,' British Journal of Industrial Relations, 28(2), pp. 165-177.

Disney, R., A. Gosling and S. Machin (1995), 'British unions in decline: determinants of the 1980s fall in union recognition,' Industrial and Labor Relations Review, 48(3), pp. 403419. https://doi.org/10.1177/001979399504800302

Dodgeon, B., A. Goodman, J. Johnson and P. Shepherd (2014), 'Perinatal Mortality Survey - additional variables,' Centre for Longitudinal Studies, Institute of Education, London.

Duncan, G. J. and Stafford, F. P. (1980), 'Do union members receive compensating wage differentials?, The American Economic Review, 70(3), pp. 355-371.

Elias, P. and Blanchflower, D. G. (1989), Occupational Earnings and Work Histories: Who Gets the Good Jjobs? Department of Employment Research Paper No. 68.

Freeman, R.B. (1978), 'Job satisfaction as an economic variable,' American Economic Review, 68(2), pp.135-41.

Freeman, R.B. (1980), 'The exit-voice tradeoff in the labor market: unionism, job tenure, quits, and separations,' The Quarterly Journal of Economics, 94(4), pp. 643-673. https://doi.org/10.2307/1885662

Freeman, R. and J. Medoff, (1984), What Do Unions Do? Basic Books. 
Gordon, M.E. and Denisi, A.S. (1995), 'A re-examination of the relationship between union membership and job satisfaction,' Industrial and Labor Relations Review, 48(2), pp. 222236.

Green, C. and Heywood, J. (2014), 'Dissatisfied union workers: sorting revisited,' British Journal of Industrial Relations, 53(3), pp. 580-600.

Heywood, J. S., Siebert, W.S., and Wei, X. (2002), 'Worker sorting and job satisfaction: the case of union and government Jobs,' Industrial and Labor Relations Review, 55(4), pp. 595-609.

Joshi, H., Bryson, A., Ward, K. and Wilkinson, D. (2020), 'The gender gap in wages over the life course: evidence from a British cohort born in 1958,' Gender, Work \& Organization, forthcDOI:10.1111/gwao.12580

Kahn, L.B. (2010), 'The long-term labor market consequences of graduating from college in a bad economy,' Labour Economics, 17(2), pp. 303-316.

Korenman, S. and D. Neumark (2000), 'Cohort crowding and youth labor markets: a crossnational analysis', in Youth Employment and Joblessness in Advanced Countries edited by David G. Blanchflower and Richard B. Freeman, NBER and University of Chicago press.

Leigh, D. (1981), 'Do union members receive compensating wage differentials? Note,' American Economic Review, 71(5), pp. 1049-1055.

Lewis, H. G. (1963), Unionism and Relative Wages in the United States, Chicago, University of Chicago Press.

Millward, N., Bryson, A. and Forth, J. (2000), All Change at Work? Routledge, London.

Pearson, H. (2016), The Life Project: The extraordinary story of our ordinary lives, Allen Lane, Penguin Random House UK.

Powdthavee, N. (2011), 'Anticipation, free-rider problems, and adaptation to trade unions: re-examining the curious case of dissatisfied union members,' Industrial and Labor Relations Review, 64(5), pp. 1000-1019.

Sargent, J. and Blanchflower, D. G. (1994), 'Obesity and stature in adolescence and earnings in young adulthood,' Archives of Pediatrics and Adolescent Medicine, 148, pp. 681-687.

Stewart, M. (1987), 'Collective bargaining arrangements, closed shops and relative pay', The Economic Journal, 97, 140-155 
Table 1. UK NCDS4 Satisfaction equations, workers only

\begin{tabular}{|c|c|c|c|c|c|c|}
\hline & Overall & Pay. & Physical conditions & Job organization & Job interest & Overall \\
\hline Union & $-.0058(0.27)$ & $+.1425(6.42)$ & $-.1286(6.12)$ & $-.2422(10.06)$ & $-.0677(3.27)$ & $-.0558(2.37)$ \\
\hline Male & $-.1400(6.23)$ & $-.2179(9.49)$ & $-.1292(5.95)$ & $-.2864(11.49)$ & $-.0072(0.33)$ & $-.1940(7.95)$ \\
\hline Part-time & $.1285(2.75)$ & $.2405(5.00)$ & $.1240(2.74)$ & $.0745(1.43)$ & $-.0498(1.11)$ & $.1291(2.49)$ \\
\hline Self-employed & $.3821(8.27)$ & $.3617(7.42)$ & $.1372(3.04)$ & $.6873(12.62)$ & $.3368(7.63)$ & $.0768(2.04)$ \\
\hline Log hourly pay & & & & & & $.2879(8.65)$ \\
\hline Constant & 4.2322 & 3.4191 & 4.2977 & 3.6586 & 4.3309 & 2.3741 \\
\hline Adjusted $\mathrm{R}^{2}$ & .0170 & .0285 & .0120 & .0505 & .0220 & .0215 \\
\hline $\mathrm{N}$ & 9134 & 9087 & 9111 & 9032 & 9098 & 8162 \\
\hline
\end{tabular}

All equations include region (10) and education (15) controls. T-statistics in parentheses.

Table 2. UK NCDS7 Job Satisfaction equations, workers only

\begin{tabular}{|c|c|c|c|c|c|c|}
\hline Union NCDS6 & & $-.1063(4.03)$ & & & $-.0726(2.27)$ & $-.0882(2.30)$ \\
\hline Union NCDS5 & & & $-.0688(2.53)$ & & $-.0259(0.81)$ & $-.0316(0.81)$ \\
\hline Union NCDS4 & & & & $-.0235(0.83)$ & & $.0253(0.77)$ \\
\hline Male & $-.1668(6.27)$ & $-.1733(6.38)$ & $-.1683(5.94)$ & $-.1681(5.12)$ & $-.1816(6.28)$ & $-.1828(5.25)$ \\
\hline Part-time & $.0174(0.54)$ & $-.0030(0.09)$ & $.0073(0.21)$ & $-.0002(0.01)$ & $-.0067(0.19)$ & $-.0284(0.67)$ \\
\hline Self-employed & $.2849(8.62)$ & $.2617(7.58)$ & $.2570(7.20)$ & $.2859(7.38)$ & $.2564(6.94)$ & $.2454(5.80)$ \\
\hline Constant & 4.1336 & 4.2121 & 4.1626 & 4.1526 & 4.2043 & 4.2301 \\
\hline Adjusted $\mathrm{R}^{2}$ & .0134 & .0156 & .0141 & .0152 & .0151 & .0167 \\
\hline $\mathrm{N}$ & 8302 & 7905 & 7372 & 5651 & 7061 & 4955 \\
\hline
\end{tabular}

All equations include region (10) and education (15) controls. T-statistics in parentheses. 
Table 3. UK NCDS8 Satisfaction equations, workers only

$\begin{array}{lcccccr}\text { Union NCDS8 } & -.1527(6.10) & & & & -.1357(4.75) & -.0744(2.02) \\ \text { Union NCDS6 } & & -.0904(3.81) & & & -.0355(1.34) & -.0491(1.30) \\ \text { Union NCDS5 } & & & -.0653(2.67) & & -.0259(0.73) \\ \text { Union NCDS4 } & & & & -.0617(2.40) & -.0210(0.71) \\ \text { Male } & -.1448(6.18) & -.1493(6.19) & -.1264(5.02) & -.1729(5.92) & -.1478(6.14) & -.1479(4.75) \\ \text { Part-time } & -.0153(0.54) & -.0076(0.26) & -.0039(0.13) & -.0551(1.53) & -.0152(0.52) & -.0667(1.76) \\ \text { Self-employed } & .1198(4.08) & .1427(4.70) & .1287(4.13) & .1349(3.91) & .1234(4.03) & .0947(2.49) \\ & & & & & & \\ \text { Constant } & 4.2468 & 4.2304 & 4.1882 & 4.2148 & 4.2529 & 4.2191 \\ \text { Adjusted R } & .0131 & .0110 & .0083 & .0105 & .0139 & .0117 \\ \mathrm{~N} & 8,235 & 7,736 & 7,194 & 5,552 & 7734 & 4830\end{array}$

All equations include region (10) and education (15) controls. T-statistics in parentheses.

Table 4. UK NCDS9 Satisfaction equations, workers only

\section{Union NCDS8 \\ Union NCDS6 \\ Union NCDS5}

Male

Part-time

Self-employed

$$
-.1743(5.65)
$$$$
-.1017(3.73)
$$$$
.0794(2.55)
$$$$
.2232(7.03)
$$

Job satisfaction ncds8

Dissatisfied

Neither

Somewhat satisfied

Very satisfied

$\begin{array}{lcccc}\text { Constant } & 4.0827 & 4.1311 & 4.1057 & 4.0616 \\ \text { Adjusted } \mathrm{R}^{2} & .0092 & .0134 & .0105 & .0112 \\ \mathrm{~N} & 6,942 & 6,161 & 6,231 & 5,868 \\ \text { All equations } & & & \end{array}$

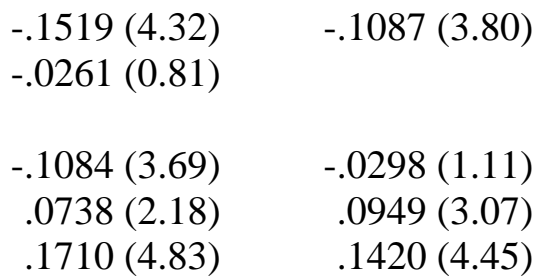

All equations include region (10) and education (15) controls. T-statistics in parentheses. 
Table 5. UK Satisfaction equations with father's social class in 1958, workers only

\begin{tabular}{|c|c|c|c|c|}
\hline & NCDS9 & NCDS8 & NCDS7 & NCDS4 \\
\hline Union NCDS8 & $-.1744(5.77)$ & $-.1493(5.81)$ & & \\
\hline Union NCDS6 & & & $-.1053(3.98)$ & \\
\hline Union4 & & & & $-.0183(0.83)$ \\
\hline Male & $-.1017(3.63)$ & $-.1368(5.70)$ & $-.1726(6.35)$ & $-.1293(5.71)$ \\
\hline Part-time & $.0770(2.41)$ & $-.0167(0.57)$ & $-.0043(0.13)$ & $.1127(3.49)$ \\
\hline Self-employed & $.1778(5.32)$ & $.1262(4.15)$ & & \\
\hline Social class at birth & Yes & Yes & Yes & Yes \\
\hline Clerical workers & $-.1388(2.23)$ & $-.0811(1.57)$ & & \\
\hline Personal service & & $.2956(2.94)$ & & \\
\hline Shop Assistants & .1397 (2.19) & & $.1456(1.69)$ & \\
\hline Foremen & $-.2647(2.87)$ & & & \\
\hline Farmers & $.1535(1.68)$ & & & $.3182(4.03)$ \\
\hline Farm workers & & .1295 (2.07) & $.1197(1.70)$ & \\
\hline Higher admin etc & & .1040 (1.97) & & \\
\hline Not in PMS & $-.0383(0.64)$ & $.0338(0.70)$ & $.0315(0.56)$ & $-.0622(1.20)$ \\
\hline Constant & 4.1529 & 4.2449 & 4.2021 & 3.8653 \\
\hline Adjusted $\mathrm{R}^{2}$ & .0171 & .0150 & .0157 & .0126 \\
\hline $\mathrm{N}$ & 6509 & 8,235 & 7,905 & 9,102 \\
\hline
\end{tabular}

All equations include region (10) and education (15) controls. Variables are measured at each sweep so in column 1, part-time and selfemployed are all at NCDS9. T-statistics in parentheses. 
Table 6. UK NCDS8 Well-being equations, workers only

$\begin{array}{lcccc} & \text { Pain } & \text { Pain at work } & \text { Managers } \text { workers } & \text { Pack in disliked job } \\ \text { Union NCDS8 } & .0743(2.17) & .0641(2.64) & -.2355(8.34) & .0731(2.72) \\ \text { Male } & -.1281(4.00) & -.0862(3.79) & -.2598(9.85) & -.1192(4.74) \\ \text { Part-time } & .0438(1.13) & .0626(2.28) & -.0797(2.50) & -.2421(7.95) \\ \text { Self-employed } & .0701(1.71) & .0587(2.02) & .1440(4.28) & -.3408(10.63) \\ & & & \text { No } \\ \text { Social class at birth } & \text { Yes } & \text { Yes } & \text { Yes } & \\ \text { Semi-skilled } & .1124(2.05) & & -.1666(3.69) & .1982(4.69) \\ \text { Admin, prof, manager } & -.1301(2.53) & -.1009(2.77) & .1293(1.57) & \\ \text { Shopkeepers } & -.2222(2.22) & -.1570(2.22) & .1205(2.03) & \\ \text { Shop assistants } & & & .0686(2.81) & \\ \text { Personal service } & & & .2563(3.00) & \\ \text { Farmers } & & & .2067(3.52) & \\ \text { Foremen } & -.2509(2.34) & -.1174(1.54) & -.0755(1.34) & \\ \text { Higher admin etc } & -.1667(2.35) & & & \\ \text { Not in PMS } & -.0767(1.12) & -.0661(1.37) & 2.0833 & .0344 \\ \text { Constant } & & & .1157 & 7,417 \\ \text { Adjusted R } & 2.6296 & 1.6470 & 7,419 & \\ \text { N } & .0154 & .0156 & & \end{array}$

Q7. How much bodily pain last 4 weeks - none (24); very mild (25); moderate (26); severe (21) very severe (32)?

Q8. How much pain interfere with work last 4 weeks - not at all (24); slightly (26); moderate (24); quite a bit (26) very severe (29)?

Q9. Management always tries to get the better of workers - strongly agree (34); agree (27); neither (23); disagree (22) disagree strongly

(17)?

Q10. Would pack in disliked job even if no other job to go to - strongly agree (16); agree (18); neither (21); disagree (26) disagree strongly (26)?

Union in NCDS8 \% in parentheses.

All equations include region (10) and education controls (8). Social class at birth refers to mother's husband. Excluded category is skilled workers. T-statistics in parentheses 


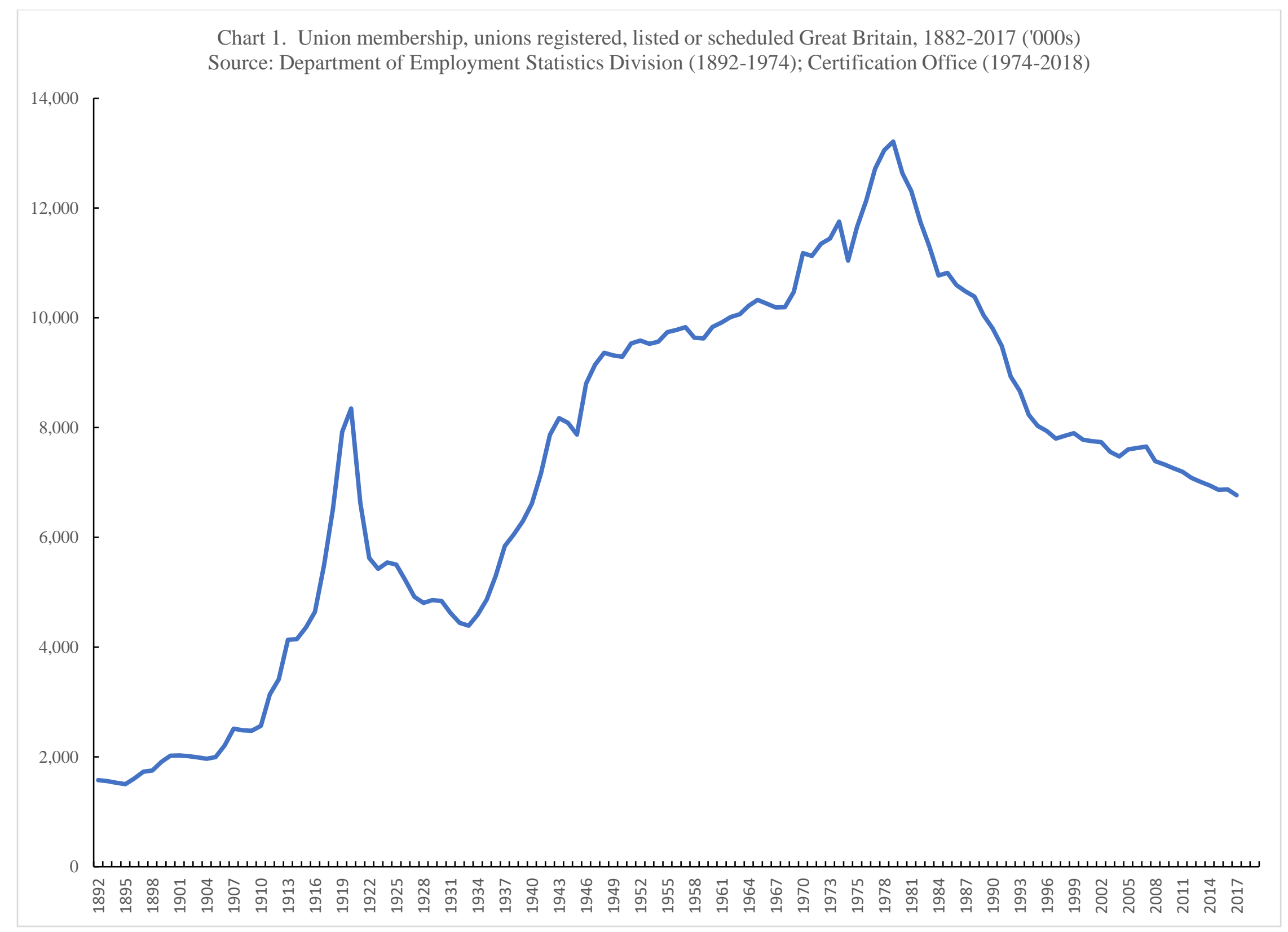




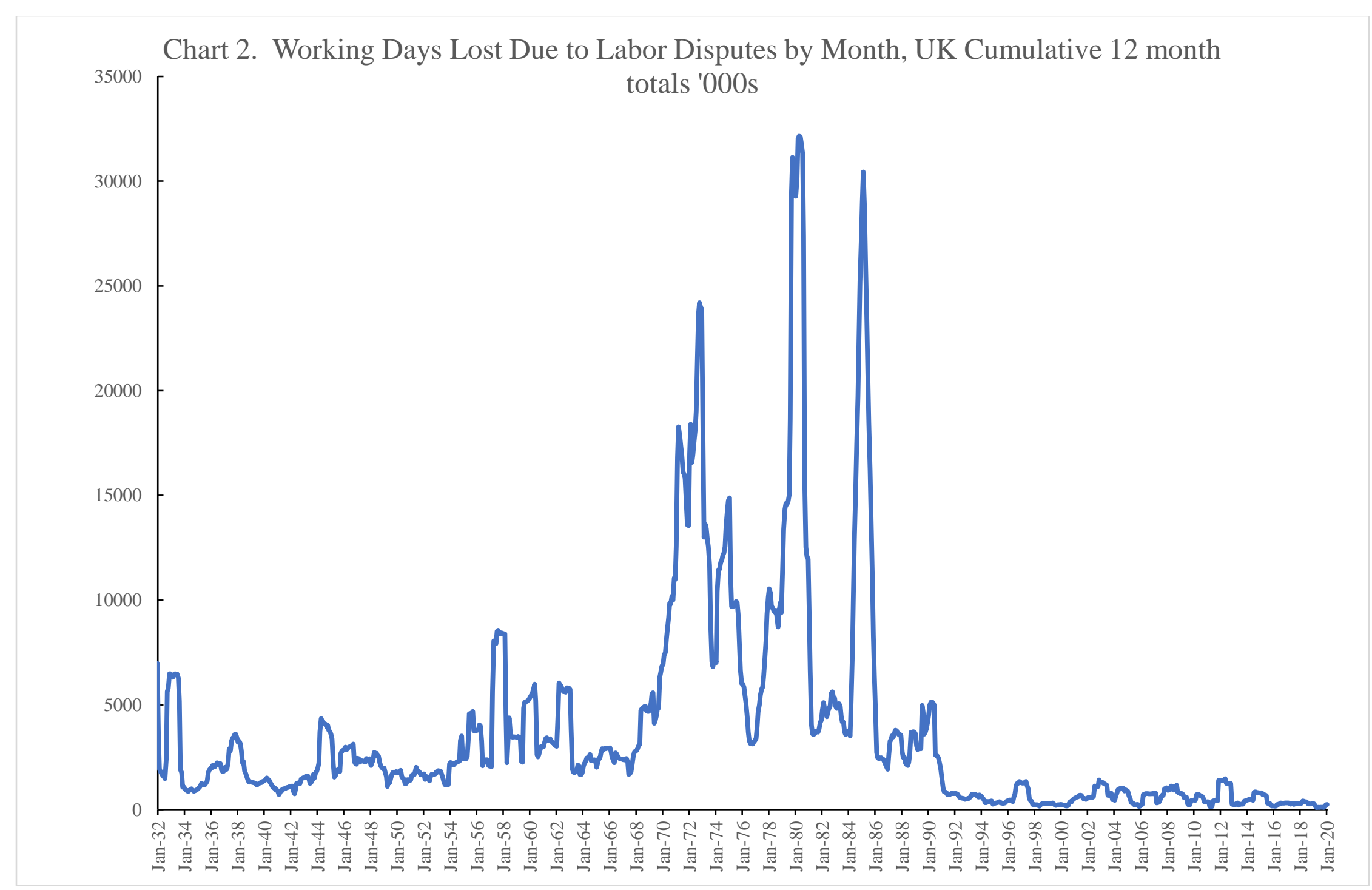

Source: ONS Labour Disputes Survey, Table LABD01, UK, not seasonally adjusted

https://www.ons.gov.uk/employmentandlabourmarket/peopleinwork/workplacedisputesandworkingconditions/datasets/labourdisputesl $\underline{\operatorname{abd} 01}$ 
Table A1. Means

$\begin{array}{lcccc} & \text { NCDS4 } & \text { NCDS7 } & \text { NCDS8 } & \text { NCDS9 } \\ \text { Very dissatisfied } & 2.8 & 4.3 & 1.7 & 2.7 \\ \text { Dissatisfied } & 9.2 & 6.5 & 5.8 & 7.3 \\ \text { Neither } & 8.1 & 4.4 & 11.2 & 12.7 \\ \text { Satisfied } & 49.8 & 38.7 & 39.8 & 38.8 \\ \text { Very satisfied } & 30.1 & 46.0 & 41.5 & 38.6 \\ \text { N } & & & & \\ & 9,176 & 8,304 & 8,254 & 7,083\end{array}$

Union membership \%

NCDS4

44.2

NCDS5

35.6

NCDS6

32.1

NCDS8

21.3

Table A2. NCDS log wage equations, workers only ages 23 and 50.

\section{NCDS8 (hourly)}

Union

(4.67)

Male

(22.47)

Part-time

Education

controls

Constant

5.2447

2.2303

Adjusted

$\mathrm{R}^{2}$

$\mathrm{N}$

.1276

.2438

$$
\begin{aligned}
& 8,179 \\
& 6,022
\end{aligned}
$$

NCDS4 (hourly)

.1806 (22.87)

$1605(20.56)$

.2781 (17.92)

No

Yes 